\title{
Which parameters - rates of survival or growth - determine the best moment for stocking trout larvae?
}

\author{
Józef Domagała, Robert Czerniawski, Małgorzata Pilecka-Rapacz
}

Received - 29 June 2015/Accepted - 30 November 2015. Published online: 31 December 2015; Inland Fisheries Institute in Olsztyn, Poland Citation: Domagała J., Czerniawski R., Pilecka-Rapacz M . 2015 - Which parameters - rates of survival or growth - determine the best moment for stocking with trout larvae? - Arch. Pol. Fish. 23: 217-224.

\begin{abstract}
The aim of this study was to determine the best moment to stock trout, Salmo trutta L., larvae into the wild. This goal was accomplished by determining weekly changes in the growth parameters of larvae that were fed in seven variants: on the day of $2 / 3$ yolk sac resorption; from the first week after the day of $2 / 3$ yolk sac resorption; from the second week after the day of $2 / 3$ yolk sac resorption; from the third week after the day of $2 / 3$ yolk sac resorption; from the fourth week after the day of $2 / 3$ yolk sac resorption; from the fifth week after the day of $2 / 3$ yolk sac resorption; from the sixth week after the day of $2 / 3$ yolk sac resorption. Based on our results, we concluded the following: 1) trout larvae are ready to start eating at the time of the resorption of $2 / 3$ of the yolk sac; 2) trout larvae can live without food for three weeks following the resorption $2 / 3$ of the yolk sac without any notable losses; 3 ) the best moment to stock trout larvae into the wild is in the period from the resorption of $2 / 3$ of the yolk sac to the third week after this resorption, so one week after full resorption. This is the optimal period to stock any waters with trout larvae.
\end{abstract}

Keywords: trout larvae, stocking, rearing, hatchery

J. Domagała, R. Czerniawski [ $\left.\Xi^{\circ}\right]$, M. Pilecka-Rapacz

Department of General Zoology,

University of Szczecin, Szczecin, Poland

e-mail: czerniawski@univ.szczecin.pl

\section{Introduction}

Although wild salmonids obtain better survival rates than hatchery-reared ones, stocking with hatchery-reared fish is still a popular way to restore salmonids in many countries. This stocking ensures better survival and growth rates than trying to restore salmon, Salmo salar L., without rearing the fry (Domagala and Bartel 1997). There seems to be a basic mis-conception about stock rehabilitation and fish farming. Today, we are not as interested in stocking and survival, but in stocking to re-establish natural populations which are otherwise declining. The survival of hatchery-reared salmonids in the wild remains low (Wiley et al. 1993, Cowx et al. 1998, Weber and Fausch 2003) in comparison to that of wild fish (Fjellheim et al. 1995). No form of rearing provides results of survival and growth comparable to the development of fish originating from natural spawning in the wild. Wild fish or stream-incubated fish attain nearly 50\% survival in their first year, which is much greater than that of hatchery-reared salmonids (Fjellheim et al. 1995, Letcher et al. 2004). The main reasons for the decline of salmonids in rivers are dams, pollution, and the lack of spawning sites. None of those major pressures is addressed by stocking. However, if stocking with hatchery-reared fish is the main means of salmonid

\footnotetext{
(c) Copyright by Stanisław Sakowicz Inland Fisheries Institute in Olsztyn.

(C) 2015 Author(s). This is an open access article licensed under the Creative Commons Attribution-NonCommercial-NoDerivs License (http://creativecommons.org/licenses/by-nc-nd/3.0/).
} 
restoration, the rearing of juvenile salmonids is still an important method in restoration programs.

Salmonid larvae are characterized by a dramatic mortality rate during their first days after release into watercourses (Cowx et al. 1998, Brown and Day 2002). Until even recently, the reasons for salmonid fry mortality rates had not been thoroughly investigated. Egglishaw and Shackley (1977) said that a period of constant population loss can be assumed to result from such things as predation, disease, starvation, and emigration, which operate at constant levels throughout the period. Additionally, low values of survival can be the result of hatchery-reared fish not being as well adapted with foraging skills for living in the wild (Brown and Day 2002, Czerniawski et al. 2010, 2015). The process of learning to find and identify prey is key for the survival of fish in the wild (Brown and Day 2002). One of the main problems of the high mortality rates of hatchery-reared salmonids larvae could also be that there seems to be no ideal time, either too early or too late, to carry out stocking. The best moment to stock salmonid larvae is when they have absorbed $2 / 3$ of their yolk sac, i.e., when they do not have a full yolk sac, but after they have eaten their first food (Goryczko 2001). Perhaps, when the larvae have absorbed more than $2 / 3$ of their yolk sac or even the whole yolk sac, we can still stock with them, because they can still catch prey. The best way is to verify this in the wild, but it is very hard to do this in situ. Thus, the easy way is to do an experiment under controlled conditions in the laboratory.

The aim of the present study was answer the follow questions: 1 ) when are trout larvae ready to eat? 2) how long can trout larvae live without food? 3) when is the best moment to stock trout larvae into the wild?

\section{Methods}

Hatchery-reared sea trout fry were used for the stocking experiment (fork length $20.79 \mathrm{~mm}$, body weight $0.0963 \mathrm{~g}$ ). Larvae were reared for seven weeks during which they were fed ad libitum on mixed live zooplankton and prepared pellet food (Skretting, Perla
Larva Proactive 4.0, contents: $62 \%$ protein and $11 \%$ lipid, pellet size $0.3-0.8 \mathrm{~mm}$ ). The water volume in each tank was $55 \mathrm{~L}$; the water temperature was kept between $6^{\circ} \mathrm{C}$ (at the beginning of rearing) and $13^{\circ} \mathrm{C}$ (at the end of rearing) with a cooling device. The density per tank was 200 fish. Rearing was performed in a closed recirculating system in seven variants of three replicates each:

1) group A - larvae fed in the day of $2 / 3$ yolk sac resorption;

2) group B - larvae fed from the first week after the day of $2 / 3$ yolk sac resorption;

3) group $C$ - larvae fed from the second week after the day of $2 / 3$ yolk sac resorption;

4) group D - larvae fed from the third week after the day of $2 / 3$ yolk sac resorption;

5) group E - larvae fed from the fourth week after the day of $2 / 3$ yolk sac resorption;

6) group F - larvae fed from the fifth week after the day of $2 / 3$ yolk sac resorption;

7) group $\mathrm{G}$ - larvae fed from the sixth week after the day of $2 / 3$ yolk sac resorption.

After the third week of the experiment, the larvae re-absorbed the whole yolk sac. The live food was copepodites and adult Cyclops sp. (Czerniawski et al. 2010, 2015). In order to simulate contact between the trout larvae and food under conditions that were similar to those in the wild, the food was supplied ad libitum. Every week, 50 larvae were caught from each tank. They were anesthetized in a MS-222 solution. Fork length $\left(\mathrm{L}_{\mathrm{F}}\right)$ was recorded to the nearest $0.5 \mathrm{~mm}$. Weight (M) was recorded to the nearest $0.1 \mathrm{mg}$. Once the fish were roused, they were placed back into the tanks. The statistical significance of the differences in the survival rate was tested with the Kruskal-Wallis test $(\mathrm{P}<0.05)$. The fork length and weight of the fish was tested with ANOVA analysis of variance and the post-hoc Tukey $t$-test $(\mathrm{P}<0.05)$.

\section{Results}

Throughout the rearing period, the fish in group A had the highest values of fork length and weight in 
Table 1

Mean values \pm SD of fork length $(\mathrm{mm})$ of reared trout $(S$. trutta) larvae. Different letters in rows indicate significant differences $(\mathrm{P}$ $<0.05)$. Group A - larvae fed on the day $2 / 3$ yolk sac resorption; group B - larvae fed from the first week after the day of $2 / 3$ yolk sac resorption; group C - larvae fed from the second week after the day of 2/3 yolk sac resorption; group D - larvae fed from the third week after the day of $2 / 3$ yolk sac resorption; group $\mathrm{E}$ - larvae fed from the fourth week after the day of $2 / 3$ yolk sac resorption; group $\mathrm{F}$ - larvae fed from the fifth week after the day of $2 / 3$ yolk sac resorption; group $\mathrm{G}$ - larvae fed from the sixth week after the day of $2 / 3$ yolk sac resorption

\begin{tabular}{|c|c|c|c|c|c|c|c|}
\hline Week & A & B & C & $\mathrm{D}$ & $\mathrm{E}$ & $\mathrm{F}$ & G \\
\hline 1 & $22.2 \pm 1.74^{\mathrm{a}}$ & $21.8 \pm 1.59^{\mathrm{a}}$ & $21.8 \pm 1.59^{\mathrm{a}}$ & $21.8 \pm 1.59^{\mathrm{a}}$ & $21.8 \pm 1.59^{\mathrm{a}}$ & $21.8 \pm 1.59^{\mathrm{a}}$ & $21.8 \pm 1.59^{a}$ \\
\hline 2 & $23.9 \pm 1.49^{\mathrm{a}}$ & $22.2 \pm 2.0^{\mathrm{b}}$ & $22.0 \pm 1.67^{b}$ & $22.0 \pm 1.67^{b}$ & $22.0 \pm 1.67^{\mathrm{b}}$ & $22.0 \pm 1.67^{b}$ & $22.0 \pm 1.67^{\mathrm{b}}$ \\
\hline 3 & $25.5 \pm 2.03^{\mathrm{a}}$ & $23.7 \pm 2.08^{b}$ & $22.3 \pm 1.77^{\mathrm{b}}$ & $22.0 \pm 1.35^{\mathrm{c}}$ & $22.0 \pm 1.35^{\mathrm{c}}$ & $22.0 \pm 1.35^{\mathrm{c}}$ & $22.0 \pm 1.35^{\circ}$ \\
\hline 4 & $28.9 \pm 1.71^{\mathrm{a}}$ & $27.9 \pm 2.27^{\mathrm{ab}}$ & $26.7 \pm 2.27^{\mathrm{b}}$ & $24.7 \pm 0.79^{c}$ & $23.2 \pm 0.95^{\mathrm{c}}$ & $23.2 \pm 0.95^{\mathrm{c}}$ & $23.2 \pm 0.95^{\circ}$ \\
\hline 5 & $31.0 \pm 1.85^{\mathrm{a}}$ & $30.8 \pm 1.28^{\mathrm{a}}$ & $28.7 \pm 1.53^{\mathrm{a}}$ & $25.6 \pm 1.71^{b}$ & $23.3 \pm 0.76^{b}$ & $23.2 \pm 0.77^{b}$ & $23.2 \pm 0.77^{\mathrm{b}}$ \\
\hline 6 & $34.0 \pm 2.41^{\mathrm{a}}$ & $33.9 \pm 2.30^{\mathrm{a}}$ & $30.1 \pm 1.35^{\mathrm{b}}$ & $26.2 \pm 1.25^{\mathrm{c}}$ & $23.6 \pm 1.22^{\mathrm{d}}$ & $22.7 \pm 1.46^{\mathrm{d}}$ & $22.5^{\mathrm{d}}$ \\
\hline 7 & $35.8 \pm 2.00^{\mathrm{a}}$ & $35.5 \pm 1.68^{\mathrm{a}}$ & $30.5 \pm 1.45^{\mathrm{b}}$ & $26.4 \pm 1,83^{\mathrm{c}}$ & $24.3 \pm 0.79^{c}$ & & \\
\hline
\end{tabular}

Table 2

Mean values of weight (g) of reared trout (S. trutta) larvae. Different letters in rows indicate significant differences $(\mathrm{P}<0.05)$. For symbols see Table 1

\begin{tabular}{|c|c|c|c|c|c|c|c|}
\hline Week & $\mathrm{A}$ & B & $\mathrm{C}$ & $\mathrm{D}$ & $\mathrm{E}$ & $\mathrm{F}$ & G \\
\hline 1 & $0.115 \pm 0.027^{\mathrm{a}}$ & $0.106 \pm 0.022^{\mathrm{a}}$ & $0.106 \pm 0.022^{\mathrm{a}}$ & $0.106 \pm 0.022^{\mathrm{a}}$ & $0.106 \pm 0.022^{\mathrm{a}}$ & $0.106 \pm 0.022^{\mathrm{a}}$ & $0.106 \pm 0.022^{\mathrm{a}}$ \\
\hline 2 & $0.145 \pm 0.025^{\mathrm{a}}$ & $0.110 \pm 0.021^{b}$ & $0.085 \pm 0.013^{\mathrm{c}}$ & $0.085 \pm 0.013^{\mathrm{c}}$ & $0.085 \pm 0.013^{\mathrm{c}}$ & $0.085 \pm 0.013^{\mathrm{c}}$ & $0.085 \pm 0.013^{\mathrm{c}}$ \\
\hline 3 & $0.180 \pm 0.034^{\mathrm{a}}$ & $0.135 \pm 0.027^{\mathrm{b}}$ & $0.104 \pm 0.038^{\mathrm{c}}$ & $0.086 \pm 0.011^{\mathrm{c}}$ & $0.086 \pm 0.011^{\mathrm{c}}$ & $0.086 \pm 0.011^{\mathrm{c}}$ & $0.086 \pm 0,011^{\mathrm{c}}$ \\
\hline 4 & $0.258 \pm 0.041^{\mathrm{a}}$ & $0.234 \pm 0.049^{\mathrm{a}}$ & $0.180 \pm 0.036^{b}$ & $0.130 \pm 0.179^{c}$ & $0.082 \pm 0.008^{c}$ & $0.082 \pm 0.008^{\mathrm{c}}$ & $0.082 \pm 0.008^{\mathrm{c}}$ \\
\hline 5 & $0.321 \pm 0.029^{\mathrm{a}}$ & $0.320 \pm 0.029^{\mathrm{a}}$ & $0.236 \pm 0.059^{b}$ & $0.165 \pm 0.046^{b}$ & $0.077 \pm 0.008^{\mathrm{c}}$ & $0.076 \pm 0.007^{\mathrm{c}}$ & $0.076 \pm 0.007^{\mathrm{C}}$ \\
\hline 6 & $0.413 \pm 0.105^{\mathrm{a}}$ & $0.415 \pm 0.108^{\mathrm{a}}$ & $0.278 \pm 0.034^{\mathrm{b}}$ & $0.180 \pm 0.027^{\mathrm{c}}$ & $0.096 \pm 0.015^{\mathrm{d}}$ & $0.071 \pm 0.011^{\mathrm{d}}$ & $0.070^{\mathrm{d}}$ \\
\hline 7 & $0.492 \pm 0.102^{\mathrm{a}}$ & $0.485 \pm 0.078^{\mathrm{a}}$ & $0.298 \pm 0.049^{\mathrm{b}}$ & $0.181 \pm 0.084^{\mathrm{c}}$ & $0.123 \pm 0.007^{\mathrm{c}}$ & & \\
\hline
\end{tabular}

comparison to other groups (Tables 1 and 2). However, after the first week of rearing, no significant differences in fork length or body weight between group $\mathrm{A}$ and the other groups was noted $(\mathrm{P}>0.05)$. In the second and third week, all the other groups had significantly lower fork lengths and body weights than $\operatorname{did}$ group $\mathrm{A}(\mathrm{P}<0.05)$. However, in the fourth week, group B (fed after the first week) was characterized by similar but insignificant growth parameters to group A until to the end of the experiment $(\mathrm{P}>0.05)$. Next, group $\mathrm{C}$, fed from the second week until the end of experiment, had significantly lower fork lengths and body weights than did groups $\mathrm{A}$ and $\mathrm{B}(\mathrm{P}$ $<0.05$ ), although these values were optimal and high enough for a survival rate in group C of $100 \%$ (Table 3). The fish in group $\mathrm{D}$, fed from the third week until the end of experiment, obtained significantly lower values of fork length and body weight than did the fish fed in the previous weeks (groups A, $\mathrm{B}$ and $\mathrm{C})(\mathrm{P}<0.05)$. Moreover, group $\mathrm{D}$, from the beginning of feeding (from the third week) to the last week, achieved significantly lower survival rates than did groups $\mathrm{A}, \mathrm{B}$, and $\mathrm{C}(\mathrm{P}<0.05)$.

It seems that group $\mathrm{E}$ was the most interesting case. This group was fed from the fourth week of the experiment, and it was characterized by similar, often insignificant values $(\mathrm{P}>0.05)$ of fork length, body weight, and survival rates in comparison with group F (fed from the fifth week) and group G (not fed). Groups E, F, and G achieved significantly lower values of fork length, body weight, and survival rates than did groups A, B, C, and D, $(\mathrm{P}<0.05)$. From the 
Table 3

Mean values of survival (\%) of reared trout (S. trutta) larvae. Different letters in rows indicate significant differences $(\mathrm{P}<0.05)$. For symbols see Table 1

\begin{tabular}{llllllll}
\hline \hline Week & $\mathrm{A}$ & $\mathrm{B}$ & $\mathrm{C}$ & $\mathrm{D}$ & $\mathrm{E}$ & $\mathrm{F}$ & $\mathrm{G}$ \\
\hline \hline 1 & $100^{\mathrm{a}}$ & $100^{\mathrm{a}}$ & $100^{\mathrm{a}}$ & $100^{\mathrm{a}}$ & $100^{\mathrm{a}}$ & $100^{\mathrm{a}}$ & $100^{\mathrm{a}}$ \\
2 & $100^{\mathrm{a}}$ & $100^{\mathrm{a}}$ & $100^{\mathrm{a}}$ & $100^{\mathrm{a}}$ & $100^{\mathrm{a}}$ & $100^{\mathrm{a}}$ & $100^{\mathrm{a}}$ \\
3 & $100^{\mathrm{a}}$ & $100^{\mathrm{a}}$ & $100^{\mathrm{a}}$ & $100^{\mathrm{a}}$ & $100^{\mathrm{a}}$ & $100^{\mathrm{a}}$ & $100^{\mathrm{a}}$ \\
4 & $100^{\mathrm{a}}$ & $100^{\mathrm{a}}$ & $100^{\mathrm{a}}$ & $88^{\mathrm{a}}$ & $65^{\mathrm{b}}$ & $71^{\mathrm{b}}$ & $65^{\mathrm{b}}$ \\
5 & $100^{\mathrm{a}}$ & $100^{\mathrm{a}}$ & $100^{\mathrm{a}}$ & $75^{\mathrm{b}}$ & $53^{\mathrm{b}}$ & $9^{\mathrm{c}}$ & $11^{\mathrm{c}}$ \\
6 & $100^{\mathrm{a}}$ & $100^{\mathrm{a}}$ & $100^{\mathrm{a}}$ & $73^{\mathrm{b}}$ & $47^{\mathrm{c}}$ & $3^{\mathrm{d}}$ & $1^{\mathrm{d}}$ \\
7 & $100^{\mathrm{a}}$ & $100^{\mathrm{a}}$ & $100^{\mathrm{a}}$ & $73^{\mathrm{b}}$ & $46^{\mathrm{c}}$ & 0 & 0 \\
\hline \hline
\end{tabular}

fifth week of the experiment groups E, F, and G were characterized by significantly lower values of growth parameters than were groups $\mathrm{A}, \mathrm{B}, \mathrm{C}$, and $\mathrm{D}(\mathrm{P}<$ 0.05 ) and from the fourth week they had significantly lower survival rates than did groups $\mathrm{A}, \mathrm{B}$, and $\mathrm{C}(\mathrm{P}<$ 0.05). Despite feeding from the fourth and fifth week, groups $\mathrm{E}$ and $\mathrm{F}$ did not obtain very good results in growth parameters or survival rates. Moreover, from the sixth week of the experiment, groups F and G achieved very low survival rates, and in the seventh week all the fish from these two groups died.

\section{Discussion}

The growth rates (fork length and body weight) of the reared fish from group A were higher than those from the experiment conducted by Czerniawski et al. (2010, 2015). In these experiments, and in the present study, the trout larvae started to eat at the same age, but the food given was different. The mixed diet (live zooplankton and pellets) used in the present study was much better in stimulating faster growth than either only zooplankton or only pellet diets given separately, as were applied in those experiments. Feeding only pellets at the beginning of trout larvae rearing (the first two or three weeks) is worse than feeding only live zooplankton. On the other hand, feeding live zooplankton after two or three weeks of rearing is worse than feeding only by a pellets. So, at the beginning of trout rearing it is advisable to use live zooplankton followed by a pellet diet (Czerniawski et al. 2009). It seems that the mixed diet used in the present study is the best way to obtain good results when rearing trout larvae. The live zooplankton drifting continually in the water stimulates the interest of the fish and appears to provoke them to attack. Morrison (1983) reported that the live zooplankton teach the trout to catch the pellets. This is a widely known method applied in many hatcheries, especially in the rearing of cyprinids or grayling, Thymallus thymallus (L.) (Wolnicki 1996, Grudniewska et al. 2007). Moreover, live zooplankton used in the rearing of juvenile salmonids designed for stocking seem to result in significantly higher survival rates than in the case of fish reared before stocking on pellet diets (Czerniawski et al. 2010, 2011, 2015).

The results of present study show that from the resorption of $2 / 3$ of the yolk sac for the next three weeks the lack of food did not have any influence on the survival of the trout larvae. However, after the third week the lack of food affected survival rates and growth parameters. The differences in these rates between the fish fed before the third week and after the third week were most significant. In the third week of the experiment, the fish re-absorbed the whole yolk sac and from this moment we observed the highest mortality among the fish that were not fed surely because of the lack of food. According to Goryczko (2001), the visible symptoms of irreversible starvation in trout larvae are weight loss and darkening 
color. As these symptoms were noted in the dead fish in our experiment, we concluded that the fry died because they did not eat. Czerniawski et al. (2009, 2010, 2015) made similar observations. It seems that the most interesting point is the moment of resorption of the whole yolk sac after the third week of the experiment among group C larvae. This group was fed at the moment of whole yolk sac resorption. Unsurprisingly these fish obtained worse growth parameters until the end of the experiment than did the larvae from groups A and B. However, the 100\% survival of group $\mathrm{C}$ can be explained by the fact that at the moment of yolk sac resorption the larva can eat, and thanks to this, they can survive. Nonetheless, after the fourth week of the experiment, and one week after yolk sac resorption, the larvae cannot eat, and they were the fish that were not fed. Thus, stocking with these larvae makes no sense, because, despite the availability food, the larvae will not eat. Goryczko (2001) claims that giving larvae food if they absorbed more than $2 / 3$ of the yolk sac made no sense, because they could not learn to catch food. Our results show that this period is little bit longer and it is about three weeks after $2 / 3$ resorption of the yolk sac. Larvae which were fed in the fourth week of the experiment had much lower survival rates than did the larvae that were fed earlier. The dead specimens had no food in their stomachs.

Each stocking release should be done after monitoring of the food base in the wild. However, in many cases, when the larvae are ready to be introduced into the water, the food conditions in streams are not optimal. So, if the optimal food base occurs in the wild one week after whole yolk sac resorption, it should not be precarious. Moreover, a longer time can cause significant losses among the stocked fish. Domagała et al. (2015) showed that in the first month of their lives trout larvae found suitable food in the streams in which they had been stocked, but it was available in very small amounts. Therefore, it is worthwhile to lengthen egg incubation in a controlled way or to release trout larvae or fry when food conditions in streams are suitable.

Our results answered the questions posed in the introduction. Trout larvae are ready to start eating when $2 / 3$ of the yolk sac is resorbed, as is generally known in the literature. The trout larvae could live without food for three weeks from the resorption of $2 / 3$ of the yolk sac without any notable losses. The best moment to stock trout larvae into the wild is in the period from the resorption of $2 / 3$ of the yolk sac until the third week after resorption, so one week after total resorption. This is the optimal period for stocking any waters with trout larvae. A lack of food in this period will not cause significant trout larva mortality. Of course, we are aware that our conclusions were drawn from the results of an ex situ study, and our results might differ from those of an in situ study; however, under controlled conditions the larvae still had contact with food and they did not seem to meet any predators. Moreover, in the wild, a constant supply of food is not possible. Thus, because of concerns about the safety of the larvae, it is better to stock until the second week after the resorption of $2 / 3$ of the yolk sac. Although, as our results show, releasing the larvae up until the third week, doing the same in the first period after total yolk sac resorption could also be effective.

Author contributions. All of the authors in conceived of the research work, performed the study, supervised the study, analyzed results, and prepared the text in equal measure.

\section{References}

Brown C., Day R.L. 2002 - The future of stock enhancements: lessons for hatchery practice from conservation biology Fish Fish. 3: 79-94.

Czerniawski R., Domagała J., Pilecka-Rapacz M. 2009 Rearing of sea trout fry (Salmo trutta m. trutta L.) - as potential stocking material, with living zooplankton and dry prepared food - EJPAU, Fisheries 12(4); http://www.ejpau.media.pl/volume12/issue4/art-14.html.

Czerniawski R., Pilecka-Rapacz M., Domagała J. 2010 - Growth and survival of brown trout fry (Salmo trutta m. fario L.) in the wild, reared in the hatchery on different feed - EJPAU, Fisheries 13(2); http://www.ejpau.media.pl/volume13/issue2/art-04.html

Czerniawski R., Pilecka-Rapacz M., Domagała J. 2011 Stocking experiment with Atlantic salmon and sea trout 
parr reared on either live prey or a pellet diet - J. Appl. Ichthyol. 27: 984-989.

Czerniawski R., Domagała J., Krepski T., Pilecka-Rapacz M. 2015 - Impact of live food on survival and growth of hatchery-reared sea trout (Salmo trutta trutta L.) parr in the wild - J. Appl. Ichthyol. 31: 95-99.

Domagala J., Bartel R. 1997 - Survival and growth of reared and wild hatch of salmon released into small streams Komun. Ryb. 1: 34-38 (in Polish).

Domagała J., Krepski T., Czerniawski R., Pilecka-Rapacz M. 2015 - Prey availability and selective feeding of sea trout (Salmo trutta L., 1758) fry stocked in small forest streams - J. Appl. Ichthyol. 31: 375-380.

Egglishaw H.J., Shackley P.E. 1977 - Growth, survival and production of juvenile salmon and trout in a Scottish stream, 1966-75 - J. Fish Biol. 11: 647-672.

Fjellheim A., Raddum G.G., Barlaup B.T. 1995 - Dispersal, growth and mortality of brown trout (Salmo trutta L.) stocked in a regulated west Norwegian river - Regul. Rivers 10: 137-145.

Goryczko K. 2001 - Trout rearing and breeding Wydawnictwo IRS, Olsztyn (in Polish).

Grudniewska J., Dobosz S., Goryczko K. 2007 - Grayling (Thymallus thymallus L.) fry rearing at the Department of Salmonid Research in Rutki - Rocz. Nauk. PZW. 20: 127-136 (in Polish).
Letcher B.H., Dubreuil T., O’Donnell M.J., Obedzinski, M., Griswold K., Nislow K.H. 2004 - Long-term consequences of variation in timing and manner of fry introduction on juvenile Atlantic salmon (Salmo salar) growth, survival, and life-history expression - Can. J. Fish. Aquat. Sci. 61: 2288-2301.

Morrison B.R.S. 1983 - Observations on the food of juvenile Atlantic salmon, Salmo salar L., reared in a Scottish hill loch - J. Fish Biol. 23: 305-313.

Cowx I.G., O’Grady K.T., Sväsand T., Skilbre O.T., Van der Meeren G.I., Holm M. 1998 - Review of morphological and behavioural differences between reared and wild individuals: implications for sea-ranching of Atlantic salmon, Salmo salar L., Atlantic cod, Gadus morhua L. and European lobster, Homarus gammarus L. - Fish. Manag. Ecol. 5: 1-18.

Weber E.D., Fausch K.D. 2003 - Interactions between hatchery and wild salmonids in streams: differences in biology and evidence for competition - Can. J. Fish. Aquatic Sci. 60: 1018-1036.

Wolnicki J. 1996 - Intensive rearing of larval and juvenile vimba, Vimba vimba (L.), fed natural and formulated diets - Pol. Arch. Hydrobiol. 43: 447-454.

Wiley R.W., Whaley R.A., Satake J.B., Fowden M. 1993 - An evaluation of the potential for training trout in hatcheries to increase post-stocking survival in streams - North Am. J. Fish. Manage. 13: 171-177. 